It is unlikely that classical MSA due to neurodegenerative condition would spontaneously remit.

This observation suggests that valproic acid withdrawal should be taken into account in patients presenting extrapyramidal features, balancing risks and benefits. Further, the clinical evidence of the relationship between valproic acid treatment and MSA features opens a new clue for further investigation of the disease pathogenesis. The mechanism of action and the related changes due to prolonged valproate use should be evaluated to better understand the underpinnings of neurodegenerative extrapyramidal diseases such as MSA.

\title{
References
}

Armon, C. et al. (1996). Reversible Parkinsonism and cognitive impairment with chronic valproate use. Neurology, 47, 626-635.

Consensus Committee of the American Autonomic Society and the Academy of Neurology (1996). Consensus statement on the definition of orthostatic hypotension, pure autonomic failure and multiple system atrophy. Neurology, 46, 1470.

Easterford, K., Clough, P., Kellet, M., Fallon, K. and Duncan, S. (2004). Reversible Parkinsonism with normal b-CIT-SPECT in patients exposed to sodium valproate. Neurology, 62, 1435-1437.

Guerrini, R., Belmonte, A., Canapicchi, R., Casalini, C. and Perucca, E. (1998). Reversible pseudoatrophy of the brain and mental deterioration associated with valproate treatment. Epilepsia, 39, 27-32.

Onofrj, M., Thomas, A. and Paci, C. (1998). Reversible Parkinsonism induced by prolonged treatment with valproate. Fournal of Neurology, 245, 794-796.

Shill, H. A. and Fife, T. D. (2000). Valproic acid toxicity mimicking multiple system atrophy. Neurology, 55, 1936-1937.

Barbara Borroni, Anna Rosati, Chiara Costanzi, Roberto

Zulli, Dicram Mardighian, Roberto Gasparotti and

Alessandro PADOVANi

Neurology Unit, University of Brescia, Italy

Email: bborroni@inwind.it

doi:10.1017/S1041610207005376

\section{The unspoken secret: sexual violence in World War II}

War is a complex, enduring trauma composed of variable forms of extreme stress, such as violence, fear of death, displacement, loss of family members, abuse and starvation (Berman, 2001). More than $90 \%$ of war victims are civilians (UNICEF, 2006). Children and women are extremely vulnerable to traumatic experiences in times of war and the risk continues even in post-war-situations (Shanks and Schull, 2000). As far as former war-children are concerned, a high 
prevalence of post-traumatic stress symptoms is apparent even six decades after World War II (Kuwert et al., 2006). In the 1990s, the world was shocked by reports about systematic and widespread rape in the former Yugoslavia and Rwanda (Shanks and Schull, 2000). The Lancet has published articles about wartime rape and demanded the development of clear strategies against sexual violence in conflict (Hargreaves, 2001). However, it can be concluded that sexual violence was and is common in nearly all crisis zones. One recent example was the rape and murder of a 14-year-old girl by U.S. soldiers of the 101st Airborne Division in Iraq (The Times, 2006).

Most researchers emphasize the timeless ubiquity of wartime rape, documented even in the Bible and in Homer's Odyssey (Gottschall, 2004). Some research has looked at different theories relating to the factors that contribute to the phenomenon on the perpetrator's side; but only a few papers highlight the victim's perspective. Recently, a Croatian study group documented post-traumatic stress and psychopathology in women who were raped in the 1991-95 war (Loncar et al., 2006). In a randomized sample of Liberian women, $50 \%$ of the participants reported war trauma and $15 \%$ gave accounts of rape (Swiss et al., 1998). Summarizing the research literature on the topic, women in conflict zones suffer from all forms of non-sexual war trauma and additionally from sexual violence. Sexual violence in conflict ranges from singular acts on one side to systematic, "strategical" mass rape in the context of ethnic cleansing on the other, as happened in former Yugoslavia (Loncar et al., 2006). With the technology of the modern media, the fact of sexual violence in today's conflicts can rarely be hidden. A good example is the movie Grbavica, winner of the "Golden Bear" at the Berlinale in 2006, which narrates the story of a raped Bosnian woman and her child in post-war Sarajevo.

Sexual violence in World War II $i$ s still a secret. At the end of World War II, it is estimated that about 1.4-1.9 million German women were raped by soldiers, mainly those of the Red Army (Sander and Johr, 2005; Messerschmidt, 2006). Because of repeated gang rapes, the total number of rapes was even higher. Rapes by U.S. and French soldiers are also documented, but were not as frequent; $10 \%$ of the women committed suicide (Messerschmidt, 2006). The number of murdered women is not known. Approximately 200,000 children were conceived by rape (Sander and Johr, 2005). It must be emphasized here that it is known that German soldiers belonging to the SS and to the Wehrmacht committed sexual violence, mainly on Russian and Jewish women, before the rape of German women by Red Army soldiers. The number of rapes is not documented but a letter of the German military police reported a "high number of rapes" at the Russian front (Sander and Johr, 2005). Nazi Germany committed crimes against humanity, culminating in the inexcusable mass murder of 6 million Jewish people. This is why it is very sensitive to conduct research on German civilian 
victims of the war - even for a young psychotraumatologist born decades after World War II. So far, no study on the post-traumatic burden of the women raped at the end of World War II has been published. Some of them were traumatized again by persecution in the German Democratic Republic, which highlights the psycho-historical fact of sequential layers of traumatization in German society (Spitzer et al., 2007). Has the time come to recognize the fate of those elderly women without minimizing the war crimes of Nazi Germany? Such a study could help to understand wartime rape from the victim's perspective and its effects on later life, on post-traumatic symptoms and on post-traumatic growth. The children of the rapes could tell about their search for identity, which would help to understand the effects of intergenerational transmission of war trauma. The title of the 2007 European Conference on Traumatic Stress in Croatia is "Truth and trust after trauma" - the truth of the individual victim comes first.

\section{References}

Berman, H. (2001). Children and war: current understandings and future directions. Public Health Nursing, 18, 243-252.

Gottschall, J. (2004). Explaining wartime rape. Fournal of Sex Research, 41, 129-136.

Hargreaves, S. (2001). Rape as a war crime: putting policy into practice. Lancet, 357, 737.

Kuwert, P., Spitzer, C., Trader, A., Freyberger, H. J. and Ermann, M. (2006). Sixty years later: post-traumatic stress symptoms and current psychopathology in former German children of World War II. International Psychogeriatrics. DOI: 10.1017/S104161020600442X.

Loncar, M., Medved, V., Jovanovic, N. and Hotujac, L. (2006). Psychological consequences of rape on women in 1991-1995 war in Croatia and Bosnia and Herzegovina. Croatian Medical Fournal, 47, 67-75.

Messerschmidt, J. W. (2006). Review symposium. The forgotten victims of World War II: masculinities and rape in Berlin, 1945. Violence Against Women, 12, 706-712.

Sander, H. and Johr, B. (2005). Befreier und Befreite. Krieg, Vergewaltigung, Kinder. Frankfurt/Main: Fischer Verlag.

Shanks, L. and Schull, M. J. (2000). Rape in war: the humanitarian response. Canadian Medical Association fournal, 163, 1152-1156.

Spitzer, C. et al. (2007). Observed, pursued, disintegrated - mental disorders among victims of non-criminal repressions in the former GDR. Psychiatrische Praxis, 34, 81-86.

Swiss, S. et al. (1998). Violence against women during the Liberian civil conflict. $\mathcal{F} A M A, 279$, 625-629.

The Times (2006). Two US soldiers guilty of separate murders in Iraq. 16 November.

UNICEF (2006), www.unicef.org.

\section{Philipp Kuwert and Harald JÜrgen Freyberger}

Department of Psychiatry and Psychotherapy, Ernst-Moritz-Arndt University of Greifswald, Stralsund, Germany

Email: kuwert@uni-greifswald.de 